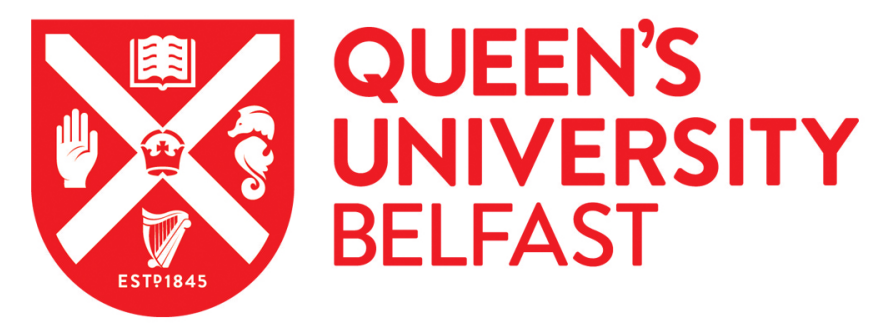

\title{
Narratives of the EU in Israel/Palestine: narrative "stickiness" and the formation of expectations
}

Miskimmon, A., \& O'Loughlin, B. (2019). Narratives of the EU in Israel/Palestine: narrative "stickiness" and the formation of expectations. European Security, 28(3), 268-283. https://doi.org/10.1080/09662839.2019.1648258

\author{
Published in: \\ European Security
}

Document Version:

Peer reviewed version

Queen's University Belfast - Research Portal:

Link to publication record in Queen's University Belfast Research Portal

Publisher rights

(C) 2019 Informa UK Limited, trading as Taylor \& Francis Group. This work is made available online in accordance with the publisher's policies. Please refer to any applicable terms of use of the publisher.

\section{General rights}

Copyright for the publications made accessible via the Queen's University Belfast Research Portal is retained by the author(s) and / or other copyright owners and it is a condition of accessing these publications that users recognise and abide by the legal requirements associated with these rights.

Take down policy

The Research Portal is Queen's institutional repository that provides access to Queen's research output. Every effort has been made to ensure that content in the Research Portal does not infringe any person's rights, or applicable UK laws. If you discover content in the Research Portal that you believe breaches copyright or violates any law, please contact openaccess@qub.ac.uk. 
Narratives of the EU in Israel/Palestine: Narrative "stickiness" and the formation of expectations ${ }^{1}$

\begin{abstract}
Analysis of narrative can help identify the expectations actors hold about each other in international relations. This article triangulates a mix of elite interviews, media content analysis and an original Q-sort public opinion methodology to map the presence of narratives about EU relations among young Israelis and Palestinians. Our aim is not to explain the effects of EU public diplomacy in these countries. Instead we aim to identify the narrative "terrain" or conditions that the EU communicates to and with and, drawing on feminist and everyday narrative studies, to examine the role of affect and identity to explain why some narratives are more "sticky" than others in those societies. We find, first, a broad recognition that the EU's capacity to act in international relations is necessary but limited in the face of greater challenges in the international system, and indeed, within the EU itself. This suggests a shift from Hill's (1993) conception of the 'capabilities-expectations gap' which dogged the emergence of the EU as a foreign policy actor in the 1990s and 2000s. Participants' narratives reflect the growing pragmatism in the EU's foreign policy outlined in the European Global Strategy. We find, second, little evidence that young people radically reshape the narratives they encounter in their public spheres, but nevertheless some important divisions emerge that pose problems for how EU policymakers can communicate consistently without dismaying some citizens in third countries. We argue that for EU communication to
\end{abstract}

\footnotetext{
${ }^{1} \mathrm{We}$ are grateful to many research assistants who will be thanked in the final article if it is accepted.
} 
have credibility, it must work with the grain of national publics' longstanding and "sticky" narratives of the international system and the character of states within it.

\section{Introduction: Analysing the conditions of narrative reception}

The study of diplomacy and security policy has overwhelmingly focused on how actors have sought to impact the behaviour of third parties in material and non-material ways. Communication has been central to this - both coercive and cooperative - as actors have either sought to force their advantage, or seek collaborative agreements to tackle shared challenges. Within International Relations (IR) in general, the recent narrative turn or 'paradigm' has also focused on the projection of narratives by actors (Bentley, 2017: 558). Less attention has been given to how this communication is received, and indeed, how diplomacy in all its guises moves through today's complex media ecology. This article presents a means to chart the terrain of reception of diplomatic narratives. We use data from an EU-funded project exploring perceptions of the EU in its neighbourhood. ${ }^{2}$ It examines how EU narratives are present or absent in the media system of Israel and Palestine. The aim of this paper is to examine the conditions of reception of EU diplomacy - from young people in Israel and Palestine. In doing this we are responding to Manners and Murray's call for greater focus on how the EU's narratives are formed, projected and received by non-EU nationals:

\footnotetext{
${ }^{2}$ Data presented is from a three-year research project called "Crisis, Conflict and Critical Diplomacy: EU Perceptions in Ukraine and Israel/Palestine" $\left(\mathrm{C}^{3} \mathrm{EU}\right)$, supported by the Jean Monnet Programme of the Erasmus+.
} 
Research pathways could usefully develop an examination of how, and by whom, many of the EU narratives are formulated; why and when they are projected; and how they are perceived by their recipients, both within the EU and in an international context. (Manners and Murray, 2016, p.199)

Manners and Murray's call builds on our conception of strategic narrative. We define strategic narratives as 'a means for political actors to construct a shared meaning of the past, present and future of international politics to shape the behaviour of domestic and international actors (Miskimmon et al., 2013, p.2). Strategic narrative is understood as both a cyclical progression of three interwoven processes of formation of narratives, projection of narratives and reception of narratives, and in terms of narrative type - identity narratives, policy narratives and narratives of the international system (Ibid.). Each narrative has a setting, plot involving an obstacle to overcome, characters, tools they use to address the obstacle, and an orientation towards desirable or undesirable endings (Burke, 1966; Shanahan, Jones and McBeth, 2011). For instance, the EU Commission may form a narrative in Brussels and project it locally in Jerusalem via cultural activities organized by the EU delegation that is received by local Israelis and Palestinians; it may be a narrative about the EU as a helpful, powerful character within a multilateral but uncertain international system, in which the EU wants to cooperate with Israel/Palestine on issues of security cooperation or economic development. Yet Israelis and Palestinians will have their own narrative understandings of how their country may move forward in that system, and they may not accept a characterization of the EU as a benevolent neighbour. In such circumstances, the EU narrative would prove ineffective and possibly even counter-productive. Our aim is to elicit those pre-existing narratives on the ground in 
a particular set of locations. We draw upon the analogy of former Secretary of State George P. Shultz (1997) who suggested diplomacy is like gardening: "You get the weeds out when they are small. You also build confidence and understanding. Then, when a crisis arises, you have a solid base from which to work"

Analysing the conditions of reception of diplomatic communication in third countries is vital in deepening our understanding of communication in crises. Scholars such as Schumacher (2015) have highlighted the challenges the EU faces to project a narrative in the neighbourhood that legitimises its role. However, analysing the condition of reception of narratives presents significant methodological challenges. This study of reception has emerged from the creation of three new data sets. First, a large content analysis of the reporting of EU issues within the news media in Israel/Palestine. Second, elite interview analysis to elicit elites' perceptions of the EU's role in crisis management. On the basis of these first two data sets we then extracted core narrative statements about the EU and its role in crisis management and set up a Q-Sort study of Israeli and Palestinian university students to investigate what narratives those young people held about the EU and its role on citizens in third countries. Studies of political socialization show that the $18-30$ age period is most important in the formation of political attitudes and identities (Flanagan et al, 2015; Neundorf et al, 2013). They matter because they generate political change through 'generational replacement', taking over positions of power in the following decades (Franklin et al, 2004). 
Our theorization of narrative "stickiness" is generated through our engagement with the literatures on ordinary citizens' "everyday" narratives. Stanley and Jackson suggest that much of the literature avoids three core problems:

First, we simply do not know how audiences receive or mediate elite-driven discourses and ideas in any particular scenario. Do non-elites simply internalise the justifications of the elite in a largely unproblematic way? To what extent do elite discourses speak to the ways in which non-elites make sense of the world? Do everyday people openly deliberate and discuss otherwise contentious political change? If so, do they resist the official line from those with formal authority, or do they instead acquiesce? We know surprising little about how elite discourses work in their interaction with nonelite audiences in the real world... (Stanley and Jackson, 2016: 227)

Further, scholars of world affairs focus on the narratives projected by leaders (Snyder, 2018; van Herpen, 2016). They rarely examine how ordinary people engage with those narratives or what pre-existing narratives people hold and thus why certain narratives become convincing to particular groups, which is the focus of this article.

There is an existing literature in International Relations that looks at how citizens engage with and produce their own narratives about political affairs. Rather than treat people's attitudes as data points to aggregate into "public opinion" (Sylvester, 2013; Wibben, 2011), scholars began to research how citizens produced narratives as they engaged with dilemmas in their personal lives and news media and face-to-face conversations about politics on a daily basis (Gillespie, 2002). Feminist scholars 
began to research how such narratives formed in private and public spaces and how hierarchies of voice determined whose narratives reached the public sphere (e.g. Wibben, 2011). Methodologies used include ethnographic fieldwork, focus groups, interviews, as well as textual analysis of cultural products to identify whose perspective are present or absent in film, television, and so on (e.g. Pears, 2017).

This literature is invaluable for two reasons. It generates an understanding of how lay members of the public engage with politics in ways often overlooked in institutional analysis, highlighting how and why elite narratives may make no sense or generate resistance or indifference among target populations (MacGinty and Firchow, 2016). In addition, these studies illuminate the 'discursive environment' that elite narratives are projected into (da Silva and Crilley, 2017: 164). This literature explores the terrain that strategic narratives operate on and in.

Within that terrain a recurring finding is that citizens' narratives differ from elites' narratives (Gillespie et al, 2010; Jarvis and Lister, 2016) and that in some groups this generates resistance and even mobilizes citizens to use political agency to assert their narratives in the public sphere (O'Loughlin and Gillespie, 2012). A second widespread finding is that citizens' narratives are inconsistent and display knowledge gaps and this creates frustration for them because they are invested in political matters and desire a news media that would provide them with reliable information (see for example Jackson and Hall, 2016).

There are some methodological problems in this literature. First, many studies treat narrative and discourse interchangeably rather than identify the structural elements of 
participants' narratives (e.g. da Silva and Crilley, 2017; Jackson and Hall, 2016; an exception is Seabrooke and Thomsen, 2016). As Wibben argues, the systematic, formal analysis of language allows precision about how identities are constructed and contested in language - the point is to use structural analysis to help explain a broader political process (see Wibben, 2011: 44-47, 52). Second, the desire to avoid imposing categories on the world of everyday lived experience of politics runs up against the problem of ultimately having to select data and cases. Jarvis calls for inductive "vernacular" research that avoids researching the narratives of a pre-defined group but then recommends 'a charting of the connections - or lack thereof - between diverse elite and everyday narratives' (Jarvis, 2019: 117). That requires deciding what count as elite or everyday narratives, necessitating the conceptualization of groups. In this article we will test this connection by comparing how students in different countries respond to and re-mix the elite narratives present in their public spheres.

Analysis of narratives allows us to understand how identities of self and other are produced and contested. We have argued that in international relations three types of narrative are at play: actors narrate the international system, and they have narratives about specific policy issues, but identity narratives cohere both: in a given type of system, actors with certain identities - those who identify as great powers, rising powers, small states, global NGOs, local insurgents, a multinational corporation, and so on - will feel norms of appropriateness about how they should behave (Miskimmon et al, 2013; 2017). This shapes expectations about who should take responsibility for addressing policy problems. In feminist security studies the focus remains on understanding mechanisms through which those of differing identities can 
co-exist. But what is unclear is why some narratives about certain identities or issues “stick" (Solomon, 2017).

One answer may be actors' emotional investment in identities. Solomon (2017) argues that US policymakers' desires for the US to be tough and responsible and Iran to act as an disruptive but sometimes audacious challenger that has driven US-Iran diplomatic negotiations in the past decade. We argue, here, that this affective charge is identifiable analytically through analysis of narrative, since in US foreign policy narratives we can identify how Iran and its actions are characterized and what policy responses the US projects as likely to bring about an desired resolution. Overall then, stickiness of a narrative about an actor occurs when that actor, as an object to be encountered, becomes imbued with affect. This becomes present as data through the narratives the different actors communicate. Feelings about actors and claims about how to act towards them are put into words (White, 1980), and are thus amenable to narrative analysis.

In our research we will explore how young people relate to the EU, and what if any kind of attachments they desire between the EU and their country. This study fits into a constitutive logic in International Relations whereby certain meanings are attributed to actors, to events, and to processes of historical change and those meanings are then considered to guide action (Epstein, 2008; Hansen, 2006; Miskimmon et al., 2013, 2017). Our analysis indicates a broad recognition that there are limitations to what the EU can do international relations in the face of greater challenges in the international system, and indeed, within the EU itself -- a shift from Christopher Hill's (1993) conception of the 'capabilities-expectations gap' which limited the emergence of the 
EU as a foreign policy actor in the 1990s and 2000s. This reflects a growing pragmatism in the EU's foreign policy outlined in the European Global Strategy. But the reason the young people in each country view the EU acting as a more pragmatic actor can be understood in terms of the embedded identity narratives that prevail in those countries, as well as their understandings of how the international system work. These are "sticky" narratives and the EU's limitations are viewed through the prism of those narratives. Israeli respondents depicted a world of hard power and uncertainty, and suggested the EU cannot act assertively to count as a key player in such a world. In Palestine, the ineffectiveness of the EU (despite its aid being appreciated) reflects the longstanding ineffectiveness of the international community as a whole.

Our analysis has three significant implications for the study of narrative in IR. First, narratives shape how actors understand what is in their interest in any given systemic configuration in international affairs. Second, narratives affect why certain events and those involved in them are seen as meaningful, or not. For example are the main protagonists in an alliance, with historical shared goals and sacrifices; are events understood as one of a sequence or as isolated; and so on. Finally, once we have identified the range of narratives among a given social cohort, in particular the identity narratives through which a group characterise their nation-state and its allies or adversaries, and what they perceive to be desirable and what they consider to be realistic, then policy makers have the potential to exploit 'intolerable incongruities' (Bially Mattern, 2005) between a group's hopes and realities. This creates scope for narrative agency and potential influence. For instance, in Palestinian elite interviews in this project we find perceptions that the EU will stand up to Russia but not to Israel 
when each occupies external territory. This incongruity allows interviews to depict the EU as hypocritical, self-serving, and putting cheap talk ahead of genuine commitment to the consistent application of international law.

The narratives people hold particularly about the international system and protagonists' identities indicate how we would expect them to react towards or engage with an external actor like the EU. This has implications for our understanding of how interests are formed, why events become meaningful, and the degree of credibility or trust felt by individuals about external actors. These are all findings about how narratives constitute the world for people. Amid much hot air about battles of narratives, we believe this is the foundation for any understanding of the role of narratives in International Relations.

This article takes the unusual position, then, of bringing to bear qualitative and quantitative analysis of narratives through original empirical data to generate claims of a constitutive nature. It is a first step in our research of ordinary citizens' engagement with strategic narratives of international affairs circulating in public discourse and the narratives they hold.

\section{Data and Methodology}

$\underline{\text { How Q methodology works }}$ 
Q-sort is a method that allows participants to construct personal opinion maps by organizing a set of narrative statements on a particular issue area. Participants are presented with statements about an issue and must re-arrange them into a narrative ordering that makes sense to them, and then justify their choices. Across a group of participants, this allows researchers to identify the patterned ways in which a cohort of a society narrate a given issue. It involves three formal steps. First, we identified a set of statements about the Ukraine and Israel-Palestine crises. Second, each participant ranked each of these statements on a symmetrical Q sort grid, ranging from -4 to +4 . This forced distribution captures very strong agreements and disagreements (one respectively) and allows four neutral statements.

Table 1: Q sort distribution

Etrongly Disagree Neutral Strongly Agree

\begin{tabular}{|c|c|c|c|c|c|c|c|c|}
\hline-4 & -3 & -2 & -1 & 0 & 1 & 2 & 3 & 4 \\
\hline & & & & & & & & \\
\hline & & & & & & & & \\
\hline & & & & & & & & \\
\hline & & & & & & & & \\
\hline & & & & & & & & \\
\hline & & & & & & & & \\
\hline & & & & & & & & \\
\hline & & & & & & & & \\
\hline
\end{tabular}


Analysis on the data is performed using PQMethod (Schmolck, 2014) ${ }^{3}$, a programme specifically designed to process Q sort data. Factor analysis is performed to identify the number of factors to extract from the data. These factors correspond to narrative statements that group together. The factors are rotated to capture the most meaningful perspectives identified in the Q sorts. Finally, factor arrays are generated to represent the viewpoints of each particular factor or narrative and to facilitate interpretation. Generally, three to four factors or narratives were generated. We used the KaiserGuttman criterion, Catell's scree test, Humphrey's Rule and Brown's rule as objective criteria that would give us confidence we had specific, distinguishable factors or narratives (see Watts and Stenner, 2012; Brown, 1980).

In the third step, the participants took a post-test survey in which they were given unlimited space to write down why they agreed or disagreed with statements. This allowed for qualitative analysis of their rationales for supporting certain narratives. Some students wrote very little, some a lot, and some groups spontaneously began open discussion.

Q sorts were carried out in 2016-17 by local researchers in universities in Israel (75 participants) and with Palestinians (17 participants). Researchers received methodological training from the authors at several meetings in 2016 and 2017. With Q methodology a group of around 20 participants is typical. The sample of participants and narrative statements is not intended to be statistically representative but to reflect the general diversity of perspectives on a given issue. If a narrative emerges as

\footnotetext{
${ }^{3}$ http://schmolck.userweb.mwn.de/qmethod/downpqwin.htm
} 
statistically significant but is only associated with three or four participants then the existence of that narrative is still a valid finding.

\section{Identifying the narratives in elite interviews and news media}

The project research design involved elite interview, news content and Q audience data generation and analysis. For Israel we analysed 106 news articles and 24 elite interviews (five media journalists/editors, five cultural elites, four civil society leaders, five business leaders, and five political elites). For Palestine we analysed 736 news articles and 16 interviews. For both Israel and Palestine a standardized semi-structured questionnaire was used for all interviews. Interviews were conducted by researchers in the local first language, transcribed, translated into English, stored on a passwordprotected website, and analysed for their narrative properties. How did we conduct that analysis?

We first had to establish categories through which narratives can be found in those interview transcripts and news media items. We used Burke's (1966) understanding of five properties of narrative. These properties function as an analytical guideline and framework through which narratives can be both structurally and analytically "found". Burke's first property is character or actor, which manifest in the interviews and news content in terms of focus on the EU and its members states, third countries, and regions. Second, setting/environment/scene, which manifests as the spatial framing, and we focus on whether the EU is a major or minor actor within that space. Third, Burke argues narratives contain a conflict or action, which we identify in the text through the framing of the actors' interaction, the metaphors used to conceptualise that interaction, 
and whether the action occurs within a political, economic, environmental, educational or other domain. The fourth property is the tools actors use, present in the actors' interactions, and may include policies, negotiations, technologies and other instruments to influence others. Finally, fifth, a narrative contains a resolution or goal, Burke argues. This manifested as potential solutions to conflicts in Israel-Palestine, including projections based on prior and current relations and trajectories, and possible best and worst-case scenarios.

In the news for Israel and Palestinian media, content had been coded by a research team for the manifestations used to identify the five properties - news content was coded for actors, region/space, frames, metaphors and evaluations of actions. For instance, in a news story the EU may be the primary actor but the evaluation is "EU on the brink", because of a framing of terrorism and refugee crises as entangled, and supported by conceptual metaphors of the EU as leaking container and broken vasal. This allowed us to construct narrative statements rigorously underpinned by systematic analysis of Burke's five narrative properties. The data had to be cleaned for consistency.

Critical to our analysis is that we also identified the presence of system, identity and issue narratives in the Israeli and Palestinian interviews and the Israeli and Palestinian news content. For instance, we identify how participants describe and narrate the international order, how they characterise the identity of the EU and other major powers within that order, and what policy capabilities they think the EU has on matters of, for instance, security or economic cooperation. As discussed in the Introduction, this threefold typology of narratives is central to our theorising of how narratives have effects in international relations. 
In short, narratives were deduced from elite interviews and news media because Q-sort involves first identifying the narratives in a public sphere in order to put them to the participants. Those interviews and news media were coded for the five aspects of Burke's narrative analysis and for identity, system and issue narratives. This was a task that took about six months prior to us conducting the Q-sort study.

Below, for each country we set out the prevailing narratives in their public sphere and then how participants responded to and re-forged their own narratives to reflect their own beliefs.

\section{Israel Analysis: Opportunities for Cooperation in an Uncertain World}

Data were collected on 75 participants from Israel, aged 22-34. The sample is not representative of the population by age, but is assumed to be diverse and representative of the different viewpoints regarding Israel's nationalism, future relations with the EU, the effect of refugees and terrorism, the European crisis, Europe's role in the Palestine/Israel peace process, and the changing relationship between Israel and Europe.

Interview and news content analysis led to 24 distinct statements - four metanarratives each with six associated statements -- which were ranked by each participant on a simplified q-sort grid with values range from $-4,0$ and +4 , with two statements allowing to capture very strong agreements (+4) and two statements allowing to capture very strong disagreements (-4) and the other four 
as neutral statements (0). As shown below, elite and news analysis indicated students would be exposed to the following narratives: First, the world is being remade and we live in a new world order. Here, interviewees and media reports repeated a narrative of a changing international order in which relations between the EU and Israel were framed. The EU was considered to be a shaping power in this changing landscape, with media and interviewees in Israel basing their understanding of shaping powers and nation states. The second metanarrative was the EU is on the brink. Interviewees and much of the media reporting on the EU in our sample repeated a narrative of the EU in crisis. Central to this was the EU debt crisis and its impact on EU civil society and business. Interviewees and the media suggested that Brexit will weaken the EU but not adversely effect Israel. Wider issues such as immigration were also considered a threat to the EU. There was also a suggestion within the coverage of the EU and in interviews that the EU's experience of terrorism was in some ways useful for understanding the Israeli experience. The final aspect of this narrative was that populism was perceived to be a predictable development given the wider crisis facing the EU and its member states.

The third Israeli metanarrative was Israel needs Europe. Despite the recurrent narrative of the EU in crisis, partnership with EU was stated as important for Israeli interests. For interview respondents, the US and Russia were most important influential, followed EU member state countries or China, suggesting a clear hierarchy of partner states within the international order. In interviews and news media, relations between the EU and Israel were often defined by headline issues that impact relations such as the Boycott, Divestment, Settlement (BDS) movement and the issue of labeling of products originating from settler communities. Despite these thorny issues, interviewees pointed 
to diverse relations across culture, civil society, business and politics. Media and interviewees in Israel often privileged member states as influential actors rather than the EU. Some respondents suggested that whilst they recognised the utility of an EU delegation in Israel, its profile was considered low. The fourth and final metanarrative was Israel stands alone. This expressed the idea that Israel needed to be a self-reliant actor. The EU was criticised for being too diverse and insufficiently involved in Israel's concerns. The EU was presented as weak, guilty of not helping resolve instability in the Middle East and incoherent in its engagement with Israel. Failure to be able to make take clear decisions as a diplomatic actor ensures that its ability to mediate is compromised.

From the media and elite interview data, four narratives were presented to the participants in Israel, each with six statements that reflected events, characters or dilemmas associated with that narrative. The four narratives were: first, The world order is being remade and we live in a new world order; second, The EU is on the brink; third, Israel needs Europe; and fourth, Israel stands alone.

How did participants respond to these narratives? From our analysis of the Q-sort data of students based in Israel we found they had remixed the statement to form the following factors or narratives:

\section{Israel should cooperate with the EU in an uncertain world}

Thirteen participants were significantly associated with this narrative, most agreeing with statement 1 'The World is rapidly changing and existing relationships have to be rethought' and statement 17 'the EU is Israel's friend'. This narrative was sticky for 
this group because, in an uncertain environment, the EU was an actor related to through hope and historical friendship. They chose statements that generally de-emphasised pessimism over the EU's future stability or any need to reconsider Israel-EU relations. In the post-test survey, one summarised why they did not believe Europe was in deep crisis, writing:

Europe is a continent of $600,000,000$ people, and the brutal death of 100 of them in a year shouldn't disturb them at all... there are much more important issues the crazy people bombin' in the streets

This participant added that they thought the EU should continue to expand to become a 'federation' that acts on climate change, animal rights and global healthcare. Hence, a positive identity narrative of the EU opens space for policy narratives about how to cooperate with the EU on particular issues.

\section{There needs to be a review Israeli-EU relations in an uncertain world}

Seven participants associated with this narrative. They also most agreed with statement 1 but equally most agreed with statement 4 'Israel and the EU will have to rethink their relationship due to criticism of settlements'. This was not a source of shame or injured pride, but a feeling that all relations must be judged at all times thorugh a prism of interests. They did not necessarily emphasise a negative view towards Europe - they most disagree with statement 23 'Europe's policies are the cause of anti-Semitism' but they had a pragmatic perspective of relations. This, global, pragmatic attitude is captured in the post-test response of one participant, who rationalized their ranking by 
saying, 'Israel must consider the opinions of other countries in this global world same as all other countries'.

\section{The EU can be trusted and Israel should cooperate in a conciliatory fashion}

Seven participants associated with this narrative. They most agreed with statement 13, 'Israel cannot afford to be constantly “offending” its allies'. Here there was a degree of shame about the actions of the state of Israel. While emphasizing security threats in Europe, this group generally rejected pessimism over the EU's future. The EU remained a stable entity that Israel should look to engage with.

\section{The EU is in crisis and Israel should review its relations with it.}

Eight participants' responses associated with this narrative. They expressed greater suspicion towards the EU in general and exuded confidence about Israel's relative position. They most disagreed with statement 15 , 'The EU is an important player in the Israel / Palestine peace process'. Here the feeling of the EU as a fundamentally weak entity enabled greater confidence in Israel to direct its destiny independently. In the post-test survey one said they most agreed with statements about Europe in crisis because 'its spoken a lot in the academia [sic] and the media'. This raises questions about how students acquire and evaluate political information - the 'discursive environment' or terrain within which any communication from the EU might be encountered and, according to this narrative, probably ignored (da Silva and Crilley, 2017: 164). It must be added that while this group were pessimistic about the EU, there was still a desire for positive relations. One participant who expressed this narrative said in the post-test survey, 'I'm sure that [the EU] is a real partner of Israel and it will 
remain like that. Even though, Israel always need to be ready for a "rainy day", that she might be alone.'

We find that the participants' narratives coalesce in similar ways to the narratives presented to them from the Israeli public sphere. In terms of narrative analysis, they indicate a system narrative of the world characterised by uncertainty, conflict and power shifts - there is a global scene and it is anarchic. Participants' identity narratives characterise the EU as in trouble, likely to endure in the long run, but with no efficacy regarding the Israel-Palestinian conflict. It lacks hard power tools or instruments to make a difference, many thought. There is greater divergence in characterisation of Israel. Participants present their country as either a realistic, embattled and just nation confidently standing alone or as a nation self-destructively provoking its allies, which in the post-test survey several participants blamed on 'our populist politicians'. Finally, on issue narratives several of those who characterised the EU as a stable and trustworthy actor were positive about economic and possible environmental cooperation with Europe.

In the qualitative survey responses many participants reacted strongly against the statements they were asked to rank, saying they did not capture the complexity of EUIsrael relations or wider world politics. This may indicate a willingness for a richer news diet than the relatively sensationalist Israeli media ecology. It also bears upon our methodological choices and Jarvis's (2019) suggestion of an inductive approach to citizens' narratives. Participants felt stifled by the elite narratives presented to them. However, their communication of that in the final stage of our method allowed us to 
compare their narrations to elite narratives and identify this important affective response.

\section{Palestine}

As with the study in Israel, we generated narrative statements for the Q sort in Palestine through the analysis of Palestinian media and through interviews with Palestinian elites. We analysed coverage of the EU in two newspapers - Al Kuds and Al Ayam during the period $1^{\text {st }}$ January 2016 to 30 June 2016, which amounted to 736 articles. Interviews were conducted with 17 Palestinian elites from media, culture, civil society, business and politics. From this data we generated a total of 30 statements organised around 5 distinct meta narratives found in the data.

Data were collected on 17 participants from Palestine, aged 22-32 with one outlier at 51. The sample is not representative of the population by age, but is assumed to be diverse and representative of the different viewpoints regarding Palestine's relationship with the EU. Participants were presented with the 30 distinct statements across five metanarratives listed below. Students were again asked to rank each statement with a values range from $-4,0$ and +4 . Five meta- narratives emerged from the interview and media analysis.

First, that the global order was unstable and uncertain. This was highlighted in the data with the assertion that an uncertain international environment made for greater challenges in dealing with Palestinian concerns. The second narrative evident in the data was that Palestine has always been left unresolved by the international community, 
a palpable sense that more could have been done to address the crisis. Thirdly, media reports and interviews stressed the view that the European Union is divided, fragmented and in chaos. The migration crisis, the Euro crisis and increasing tensions between member states were all pointed to reinforce this point. Fourth, a narrative that the European Union is hypocritical and that Palestine cannot trust it came through forcefully in the data. This narrative stressed the perception that the EU was inconsistent as an actor. Finally, there was also a view that, despite the challenges indicated in the data, working with the European Union is the only way to peace for Palestine and Israel.

From our analysis of the responses, two broad narratives emerged:

1. Palestinians are treated unfairly, and the EU cannot or will not help.

Five participants in the study were significanly associated with this view. The most highly ranked statement in this group was that Palestinians are constantly deprived of their human rights. For them, this narrative was sticky because the EU's actions have not provided solutions and probably will not in the future, they felt. The EU's past inability to act decisively and its present weaknesses left no reason to feel hope towards the EU. One respondent explained their ranking of this statement by writing, 'I think there are scenarios reflecting the reality of global order and how world powers view Palestine differently'. Another student suggested that they agreed most strongly with this statement because, "it is globally agreed on and it is the most contradictory statement between the countries and at the same time it is very true". Both these explanations suggest a recognition that the EU has limitations to what it can achieve to 
resolve the crisis in Palestine, without working with major powers like the US or strong Arab countries.

2. Palestine has not been a priority for the international community generally, but the EU is not incapable of providing assistance.

The second narrative was associated with four respondents. Within this narrative, the most supported statement was "Palestine is not taken seriously by the international community. Peace will always be elusive". In explaining their choice, one student suggested that this statement was 'a fact', whilst another stated they agree with this statement, 'Because that is how I feel toward the situation mentioned and that is how the reality is'. This marks an important mechanism through which affect conditions knowledge. The student's affective relation to the situation and to the EU had hardened into 'reality' per se. This reinforces a position of resignation and distance from the EU. Participants reflected on the 'always' in 'Peace will always be elusive' statement. Just as Israeli students looked to historical moments of good or bad relations with the EU, Europe or particular European nation-states, so Palestinian students justified their narratives by invoking historical events. One student mentioned the 1917 Balfour declaration as exemplifying why European elites could not be trusted.

Students tended to agree more with statements that stressed the complexities of the international system in finding an agreement and that the international system was going through change, complicating relations between states. Overall, responses indicated that whilst there was recognition of the EU's role in the Israel/Palestine crisis, it could not be viewed as central to its resolution. In terms of our strategic narrative 
theory it is striking that no Palestinian participants expressed policy narratives about cooperation on any particular issues, compared to Israeli particpants who looked for cooperation on 'climate change, animal rights and global healthcare' for instance. In the terms of Burke's pentad this also means that for the Palestinian participants there was no discussion of tools or instruments that actors could use to solve problems.

Both narratives indicate limitations to the EU's role and capacity to effect the conflict. Both narratives also indicate a scene or context (in Burke's terms) that is global, not unlike the horizon of the Israeli participants' narrative about events unfolding within an uncertain, anarchic world order. But while some Israelis felt confident in working with a stable EU within that uncertain world, for Palestinians the EU was a symptom and symbol of that uncertainty. While our analysis found that some Palestinian news media present a metanarrative working with the European Union is the only way to peace for Palestine and Israel, this narrative was rejected by the participants.

\section{Conclusions}

The descriptive aim of this study was to identity the narratives citizens hold about international affairs, and thus the narrative "terrain" or conditions that the EU communicates to and with. The explanatory aim was to theorise why some narratives are more "sticky" than others in those societies. We presented a study designed to identify the conditions the EU must communicate to and with, taking two external cases: Israel and Palestinian elites, media and young people. This allowed us to identify whether young people's narratives relate to the media and elite narratives they were exposed to. Due to our focus on the EU's international presence we were interested in how they narrate the EU and to what extent they view the EU as effective, and indeed, 
what expectations they have of the EU to act in crisis situations. The narratives of young elite students are significant because the studies of political socialization show this is the most important period that their political opinions will form and because studies of generational replacement mean this cohort may be the ones occupying positions of power and able to enact change in coming decades.

Our findings present a mixed picture. First, we find a broad recognition that there are limitations to what the EU can do international relations in the face of greater challenges in the international system, and indeed, within the EU itself. This suggests a shift from Christopher Hill's (1993) conception of the 'capabilities-expectations gap' which dogged the emergence of the EU as a foreign policy actor in the 1990s and 2000s. Whilst respondents indicated that they saw a role for the EU in international affairs, its agency for them is limited. This reflects a growing pragmatism in the EU's foreign policy outlined in the European Global Strategy and, as indicated in media and interview data, there is a recognition of the potential impact of Brexit on the EU's security and defence aspirations.

Second, we find that young people's narratives closely reflected the narratives present in media and elite discourse in their countries. This suggests the importance of embedded identity narratives that prevail in national public spheres. These are connected to understandings of how the international system works. While all Israeli media presented the international system as uncertain and full of dangers, some characterized the EU as an old friend while others characterized the EU as too weak to be worth engaging with. We see here how these enable narratives about the EU and its capabilities to "stick". Participants inhabit a media and political terrain featuring 
repeated elite characterizations of the EU as an object to relate to through a particular affect. This led them in our Q study to form narratives that closely replicate those elite narratives. We see this in turn conditions their preferences about how to engage with the EU. The only dissent was a desire among Israeli students for a more complex set of narratives.

In Palestine, EU ineffectiveness is contextualized within a narrative of being let down by the international community for a century. Decades of EU aid has not altered the situation "on the ground". This narrative is sticky because it is impossible for participants to invest hope or feel positive affect towards either the EU or the international community. The only possibility of a narrative twist, for some participants, was decisive action by a great power. However, they did not look with any hope towards the US or Arab powers, or any other power in the international system.

What do our findings mean for the study of strategic narrative reception? First and practically, our research demonstrates that the plurality of narratives held within a given cohort can be quickly identified and mapped against those prevailing in the public sphere that cohort inhabits. This shows that it is also possible to research narratives as well as the usual measures of attitudes and beliefs we find in survey research. Second, the qualitative comments remind us that to understand why people hold to different narratives we need to understand why they believe any news or information at all. Many pointed to information they took as factual, information whose veracity they disputed, or information they felt was simplistic. 
What do our findings mean for EU policymakers? Audiences will find more credible the communication of a pragmatic narrative that recognizes the limitations of the EU's capabilities, rather than continued promises about upholding human rights in all circumstances. We also find that memory and history mattered to participants. Like elites interviewed for this project, the young elite students elaborated at length on historical relations of their society to the EU, Europe and European nation-states. Through commemorations or cultural relations activities with an historical focus, this discursive terrain offers possibilities for mutual recognition and the staging of moments for shared perspectives.

We do not wish to argue that the EU should be using its narrative to alter the perceptions of citizens on the ground in the societies we research. We do argue that the EU's narrative has to at least hold a degree of cultural consonance in order to be perceived as a credible and trustworthy narrator. By 'effective' we mean that citizens are willing to at least listen to the EU's narrative and take it into account, even if they disagree with it, or disagree with EU policies they associate with it. We argue that this measure of effectiveness - being listened to - is important because it assists the EU to manage expectations about what it is likely to do. The cases of Israel and Palestine are societies in which the EU can struggle to manage expectations, either under- or overcommitting, and this can detract from EU credibility, in the eyes of these societies' elites, news media and for some of the participants in this Q-sort study. Our analysis has suggested how the management of expectations in international relations entails the management of feelings since those feelings build and harden individuals' characterization of actors. 
Future research might fruitfully conduct repeated, longitudinal Q-sorts with single populations and cohorts to identify when and under what conditions their prevailing narratives change or stay the same. Having shown it is possible to identify the conditions for narrative reception in particular countries and cohorts, future research can seek to identify whether EU communications resonate with, or contradict, those conditions, and how audiences respond to this.

\section{References:}

Bentley, M. 2017. The intervention taboo(s): Strategy and normative invalidation. Review of International Studies, 43 (3), 557-580.

Bigl, B. 2017. Fracking in the German press: securing energy supply on the eve of the 'Energiewende'-a quantitative framing-based analysis. Environmental Communication, 11 (2), 231-247.

Boudana, S., \& Segev, E. 2017. The Bias of Provocation Narratives in International News. The International Journal of Press/Politics, 22 (3), 314-332.

Brown, S. R. 1980. Political Subjectivity: Applications of Q Methodology in Political Science. New Haven, CT: Yale University Press.

Burke, K. 1966. Language as Symbolic Action. Los Angeles, CA: University of California Press. 
Da Silva, R., \& Crilley, R. 2017. "Talk about terror in our back gardens”: an analysis of online comments about British foreign fighters in Syria. Critical studies on terrorism, $10(1), 162-186$.

Epstein, C. 2008. The power of words in international relations: birth of an antiwhaling discourse. Cambridge, MA: MIT Press.

Flanagan, C., Lin, C., Luisi-Mills, H., Sambo, A., \& Hu, M. 2015. Adolescent civic development across cultures. In The Oxford handbook of human development and culture. Oxford: Oxford University Press. Available from https://www.oxfordhandbooks.com/view/10.1093/oxfordhb/9780199948550.001.000 1/oxfordhb-9780199948550-e-29 [Accessed 7 Jun. 2019].

Franklin, M. N., Lyons, P., \& Marsh, M. 2004. Generational basis of turnout decline in established democracies. Acta politica, 39 (2), 115-151.

Gillespie, M. 2002. Television, ethnicity and cultural change. London: Routledge.

Gillespie, M., Gow, J., Hoskins, A., O'Loughlin, B., \& Žveržhanovski, I. (2010).

Shifting securities: News cultures, multicultural society and legitimacy. Ethnopolitics, 9 (2), 239-253.

Hansen, L. 2006. Security as practice. Discourse Analysis and the Bosnian War, London: Routledge. 
Hill, C. 1993. The capability-expectations gap, or conceptualizing Europe's international role. JCMS: Journal of Common Market Studies, 31 (3), 305-328.

Jackson, R., \& Hall, G. 2016. Talking about terrorism: A study of vernacular discourse. Politics, 36 (3), 292-307.

Jarvis, L., \& Lister, M. 2016. What would you do? Everyday conceptions and constructions of counter-terrorism. Politics, 36 (3), 277-291.

Jarvis, L., \& Lister, M. 2013. Disconnected citizenship? The impacts of anti-terrorism policy on citizenship in the UK. Political Studies, 61 (3), 656-675.

Kobzar, S. 2016. Reporting on the Minsk II Agreement: the Effect of Russian Narratives in French and German Media. IES Policy Brief Issue 2016/17.

Manners, I., \& Murray, P. 2016. The end of a noble narrative? European integration narratives after the Nobel Peace Prize. JCMS: Journal of Common Market Studies, 54 (1), 185-202.

MacGinty, R., \& Firchow, P. 2016. Top-down and bottom-up narratives of peace and conflict. Politics, 36 (3), 308-323.

Mattern, J. B. 2005. Ordering International Politics: Identity, Crisis and Representational Force. London: Routledge. 
Miskimmon, Alister, Ben O’Loughlin, and Laura Roselle 2013. Strategic Narratives, Communication Power and the New World Order. New York: Routledge.

Miskimmon, Alister, Ben O'Loughlin, and Laura Roselle eds. 2017. Forging the World: Strategic Narratives and International Relations. Ann Arbor, MI: University of Michigan Press.

Neundorf, A., Smets, K., \& Garcia-Albacete, G. M. 2013. Homemade citizens: The development of political interest during adolescence and young adulthood. Acta politica, 48 (1), 92-116.

O'Loughlin, B., \& Gillespie, M. 2012. Dissenting citizenship? Young people and political participation in the media-security nexus. Parliamentary Affairs, 65 (1), 115 137.

Schmolck, P. (2014) 'PQMethod Download Page for Windows Users'. Available from: http://schmolck.userweb.mwn.de/qmethod/downpqwin.htm [Accessed 16 October 2017].

Schultz, G.P. 1997. Diplomacy in the Information Age. Paper presented at the Conference on Virtual Diplomacy, U.S. Institute of Peace, Washington, D.C., April 1.

Schumacher, T 2015. Uncertainty at the EU's borders: narratives of EU external relations in the revised European Neighbourhood Policy towards the southern borderlands, European Security, 24 (3), 381-401. 
Seabrooke, L., \& Thomsen, R. R. 2016. Making sense of austerity: Everyday narratives in Denmark and the United Kingdom. Politics, 36(3), 250-261.

Shanahan, Elizabeth A., Michael D. Jones, and Mark K. McBeth 2011. Policy Narratives and Policy Processes, The Policy Studies Journal, 39 (03), 535-561.

Snyder, T. 2018. The Road to Unfreedom: Russia, Europe, America. London: The Bodley Head.

Solomon, T. 2016. Identity, affective attachments, and US-Iranian nuclear politics. In M. Bentley and J. Holland (eds.) The Obama Doctrine (pp. 107-122). London: Routledge.

Stanley, L., \& Jackson, R. 2016. Introduction: Everyday narratives in world politics. Politics, 36 (3), 223-235.

Sylvester, C. 2013. Experiencing the end and afterlives of International Relations/theory. European Journal of International Relations, 19 (3), 609-626.

Van Herpen, M.H. 2016. Putin's Propaganda Machine: Soft Power and Russian Foreign Policy. London: Rowman \& Littlefield.

Watts, S. and Stenner, P. 2012 Doing Q Methodological Research: Theory, Method and Interpretation. London: Sage Publications. 
White, H. 1980. The value of narrativity in the representation of reality. Critical inquiry, 7(1), 5-27.

Wibben, A. T. 2011. Feminist security studies: A narrative approach. London and New York: Routledge. 